（日本化学会誌，1987，(11), p. 2052２057)

(C) 1987 The Chemical Society of Japan

\title{
3-(2-アミノエチルアミノ)プロピル基を有するシランで 修飾した多孔性ガラスのイオン交換膜としての性質
}

（1987 年 4 月 20 日受 理）

江 資 航・中村朝 夫・西 沢 耕 治・戸田不二緒*

細孔直径 $40 \AA ̊$ の多孔性ガラスを用い，[3-(2-アミノェチルアミノ)プロピル]トリメトキシシランを 孔内に導入することによって, アニオン選択性のイオン交換膜をつくった。未修飾の多孔性ガラス膜は ガラス表面の解離したシラノール基 $\left(\mathrm{SiO}^{-}\right)$のために表面が負に帯電している。この膜は，カチオン選 択性を示す。シラン水溶液を用いて修飾することによって多孔性ガラス膜の表面電荷の符号を反転させ ることができた。この獏を用いて, 塩化カリウム, 硝酸カリウム, 眽酸カリウムの各溶液中のアニオン の膜内に怙ける見かけの輸率を膜電位の測定によって求めた。修飾した多孔性ガラス膜の電位発生機構 は Theorell-Meyer-Sievers のモデルによって説明できる。修飾に用いたシラン水溶液の濃度が高く なるにつれて膜のイオン選択能が高くなるが，膜表面の固定電荷密度は $0.11 \mathrm{~mol} \cdot \mathrm{dm}^{-8}$ で飽和する。 塩化カリウムの溶液中に塩化銅（II）を溶かすと，修飾した多孔性ガラス膜の膜電位怟下した。これ は, 膜の固定電荷密度の減少によるものと考兵られる。このことから， $\mathrm{Cu}(\mathrm{II})$ イオンは修飾した多孔 性ガラス表面のアミノェチルアミノ基と配位していると予想される。

\section{1 粕言}

機能性の人工膜はさまざまな物質の分徼に利用することができ る。たとえば膜に固定電荷をつけると、イオンをその電荷の符号 により識別することができる。また，一定の孔径をすつ孔を借え ると、物質の分子をその大きさにより分離することができる。 ガラス表面のシラノール基は化学反応性に富み，またそのプロ トンをいろいろの官能基によって置換することによりガラス表面 の性質を变えることがでる゙。本研究は孔の直径が平均 $40 \AA$ であるューニンク社の多孔性ガラスを用いて，[3-(2-アミノェ チルアミノ)ブロピル]トリメトキシシラン（信越化学製, 以下 AEAPS と略記する)を多孔性ガラスの孔内に導入することによ って，アニオン選択性のイオン交換膜をつくった。この修飾した 多孔性ガラスのイオン選択性を膜電位の椡定によって調べたので 報告する。

\section{2 実験}

\section{1 ガラス表面の洗浄}

$15 \mathrm{~mm} \times 15 \mathrm{~mm} \times 1 \mathrm{~mm}$ の多孔性ガラス板を以下の順序で, 超 音波洗浄器を用いて洗浄した。ます，ガラス器具洗浄用洗郕の $5 \%$ 希釈液で 10 分間，つついて蒸留水で 10 分間 2 回洗浄した。 その後漫确酸で 5 分間, 蒸留水で 10 分間, $5 \times 10^{-3} \mathrm{~mol} \cdot \mathrm{dm}^{-3}$ 水酸 化ナトリウム溶液で 10 分間，最後に蒸留水で 10 分間洗浄した2!。

東京工菜大学工学部生物工学科, 152 東京都目黒区大岡 山

1) 作花济夫, 化学の湎城, 37, 363(1983).

2) J.Sagiv, J. Am. Chem. Soc., 102, 92(1980).
その後, 真空乾燥器を用いて, 真空下 $80^{\circ} \mathrm{C} て ゙ ~ 24$ 時間乾燥させ た。

\section{2 カララスの修飾}

洗浄した多孔性ガラス板を AEAPS の水溶液に浸し, 30 分間 超音波处理したのち， 2 時間室温化放固した。このガラス板を $80^{\circ} \mathrm{C}$ で 24 時間処理したのち, $0.1 \mathrm{~mol} \cdot \mathrm{dm}^{-8}$ 塩酸溶液, ついで 測定に使用する塩の溶液で洗浄して，測定に用いだ”。

このようにして得られたのはカチオン性膜である。また，中性 膜とアニオン性膜る同様につくることができるれ。その方法を図 1 に示す。

\section{3 膜電位の測定}

膜電位の测定装直としては, 電気化学計器社製の $\mathrm{pH}$ 計 HGC-10 を用い，塩化銀電極を内極とする比較電極を作用極侧と 参照極侧の両方に 2 本装着して测定を行なった。実験装置を図 2 に示す。二つのセルの間を厚さ $1 \mathrm{~mm}$ の修飾した多孔性ガラスで 隔てて，二つの溶液間の電位差を測定した。この䉓位差 $(\Delta \phi)$ か らイオンの見かけの輸率 $t_{\mathrm{app}}^{-}$を炊式によって求めた。

$$
\Delta \phi=-\left(1-2 t_{\mathrm{app}}^{-}\right)(R T / F) \ln \left(C_{\mathrm{I}} / C_{\mathrm{I}}\right)
$$

塩の種類としては塩化カリウム，硝酸カリウム，酢酸カリウム を用いた。また，それぞれの溶液中に塩化銅(II), 硝酸銅(II)， 酶酸銅（II）を含む場合にも同様にして测定を行なった。

3) R. J. Kvitek, J. F. Evans, P.W. Carr, Anal. Chim. Acta., 144, 93(1982).

4) S. H. Chang, K. M. Gooding, J. Chromatography., 120, 321(1976). 

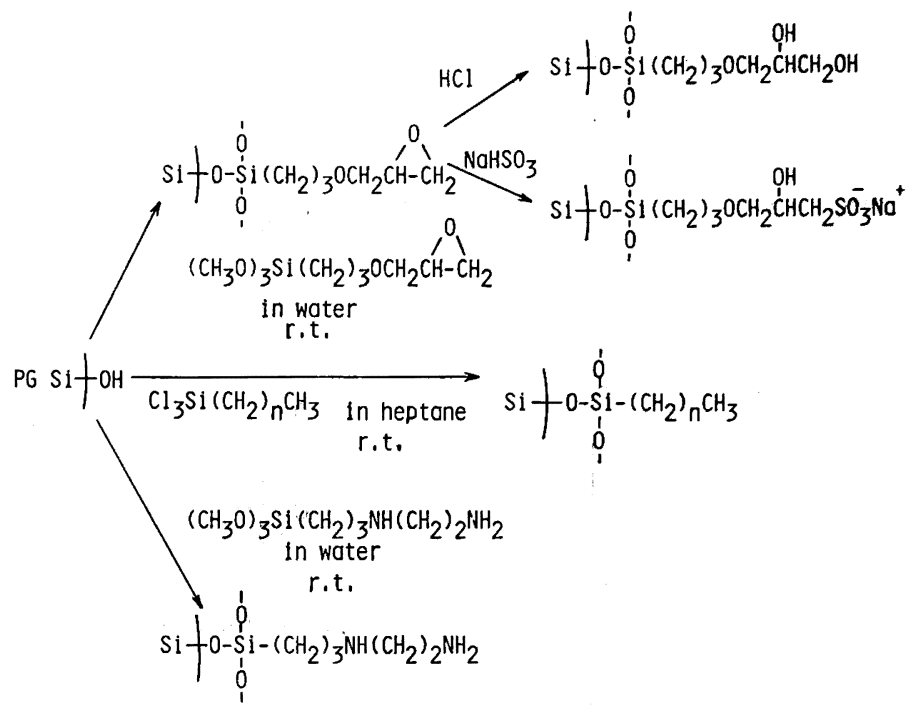

Fig. 1 The modification of porous glass surface

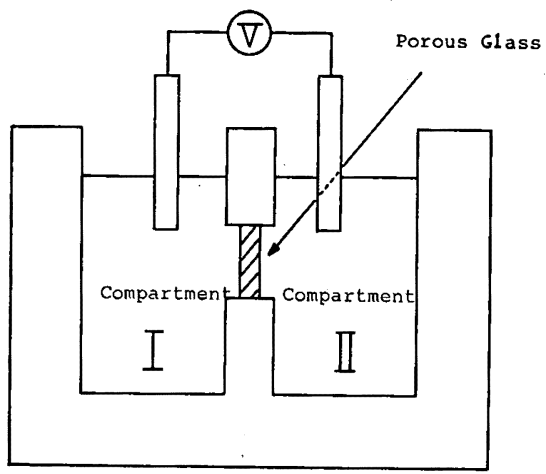

Fig. 2 Apparatus for measurement of membrane potential

Electrolyte concentration in compartment I : $C_{\mathrm{I}} \mathrm{mol} \cdot \mathrm{dm}^{-3}$; in compartment II : $C_{\mathrm{II}} \mathrm{mol}$. $\mathrm{dm}^{-3}$

Electrode immersed in each cell is $\mathrm{Ag}|\mathrm{AgCl}|$ sat. $\mathrm{KCl}$ reference electrode

\section{3 結 果}

\subsection{AEAPS 修飾膜における塩化カリウム浱度勾配による膜}

\section{電位発生}

$2 \%$ の AEAPS 水溶液を用いて修飾した多孔性ガラス板を用 い, セルの片侧の塩化カリウムの淟度をそれぞれ 0.01，0.05, $0.1,0.2,0.5,1.0 \mathrm{~mol} \cdot \mathrm{dm}^{-3}$ に固定して, 他方の塩化カリウム 濃度を変化させたときの $\mathrm{Cl}^{-}$の見かけの輸率の変化を図 3 に示 す。両側のセルに入れた溶液中の塩化カリウム濃度が十分低いと きには $t_{\mathrm{app}}^{-}$は 1 に近づき，ほぼ完全なアニオン選択性のイオン 交換膜となるが，塩化カリウムが高濃度になり $0.1 \mathrm{~mol} \cdot \mathrm{dm}^{-3}$ を 越えると，イオン選択性が急速に失われる。また，図中に示した 曲線は, 膜の左側の溶液中の塩化カリウム濃度 $\left(C_{\mathrm{I}}\right)$ を一定と し，右側の溶液中の濃度 $\left(C_{\mathrm{II}}\right)$ を变化させた場合について，TM-S の式による計算値を連続的な曲線で示したものである。膜 中の可動性カチオンとアニオンの真の輸率がともに 0.5 で, 固定

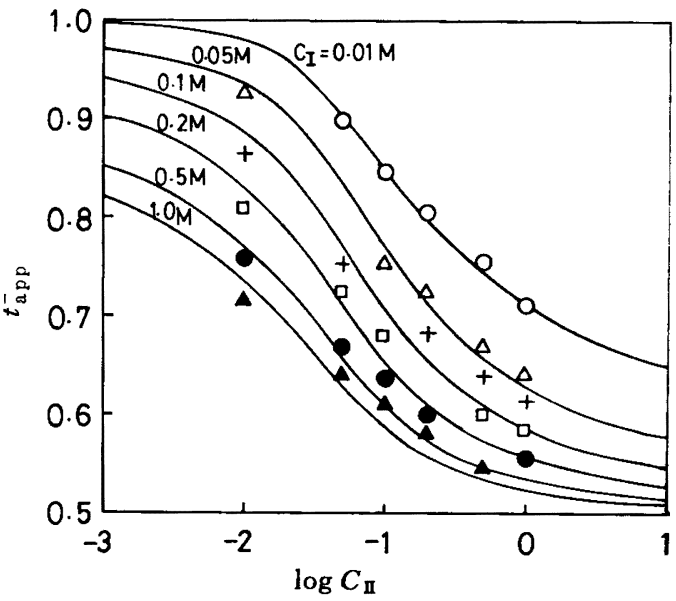

Fig. 3 Apparent transport number of chloride ion in AEAPS-modified porous glass membrane in contact with two $\mathrm{KCl}$ solutions of different concentration on both sides

Apparent transport number, $t_{\mathrm{app}}^{-}$, was calculated on the basis of Eq. 1

The curves drawn in the figure are the bestfit curves on the basis of Eq. 2 for each set of data which was obtained in the system with $\mathrm{KCl}$ solution of a specific concentration on the left side

From the curve fitting by least-square method, unknown parameters were estimated as follows: $t^{+}=t^{-}=0.5 ; X=0.09 \mathrm{~mol} \cdot \mathrm{dm}^{-3}$

$C_{\mathrm{I}}: 0.01 \mathrm{~mol} \cdot \mathrm{dm}^{-3}$

$O ; 0.05 \mathrm{~mol} \cdot \mathrm{dm}^{-3}, \triangle ; 0.1 \mathrm{~mol} \cdot \mathrm{dm}^{-3}, \quad+; 0.2$ $\mathrm{mol} \cdot \mathrm{dm}^{-8}, \square ; 0.5 \mathrm{~mol} \cdot \mathrm{dm}^{-8}, \bigcirc ; 1.0 \mathrm{~mol} \cdot \mathrm{dm}^{-3}$,

電荷密度を $0.09 \mathrm{~mol} \cdot \mathrm{dm}^{-3}$ としたときに，もっともよく実测值 に合ら曲線が得られた。 


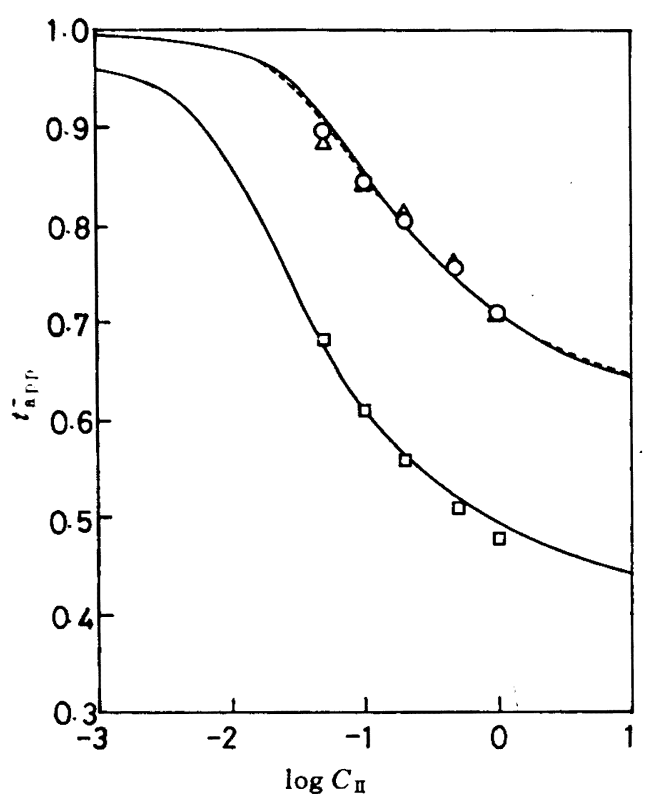

Fig. 4 Apparent transport number of anions, $t_{\mathrm{app}}^{-}$, versus $\log C_{\text {II }}$ plots of the data obtained in the membrane systems with solutions of three different kind of potassium salts

A $0.01 \mathrm{~mol} \cdot \mathrm{dm}^{-3}$ solution of potassium salt was located in the left compartment and another $C_{\text {II }} \mathrm{mol} \cdot \mathrm{dm}^{-8}$ solution of the same kind of salt was in the right compartment

Curves are the best-fit curve on the basis of Eq. 2. $\mathrm{O} ; \mathrm{KCl}, \triangle ; \mathrm{KNO}_{3}, \square ; \mathrm{CH}_{3} \mathrm{COOK}$

し，暒として程化カリウム，硝酸カリウム，酢酸カリウムを用い て行なった実検の結果を図 4 に示す。この揚合，七ルの片側の塩 の渡を $0.01 \mathrm{~mol} \cdot \mathrm{dm}^{-3}$ に固定して測定した。測定結果に対し て Theorell-Meyer-Sievers の式を䧟用してカーブフィッティン クを行ならと，塩暴度の高いところでのアニオンの見かけの輸率 は $\mathrm{Cl}^{-}, \mathrm{NO}_{3}^{-}, \mathrm{CH}_{3} \mathrm{COO}^{-}$に対して，それぞれ $0.51 ， 0.49$, 0.34 になる。これはそれぞれのアニオンのカリウム塩の水溶液 におけるアニオンの輸率によく一致している。

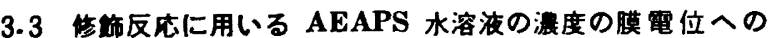

\section{影要}

1，2，3，5\%の AEAPS 水溶液を用いて修飾した多孔性ガラス を獏として，七ルの片僋の塩化カリウムの䈨度を $0.01 \mathrm{~mol} \cdot \mathrm{dm}^{-3}$ に固定して，他方の塩化カリウム丧度を变化させたとさの $\mathrm{Cl}^{-}$の 見かけの渝率の変化を図 5 に示す。AEAPS 溶夜の濃度を高くす ると，钼测される見かけの榆率は高くなるか，その変化は $3 \%$ 付 近で和する。

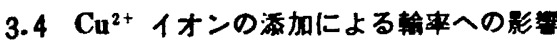

この场合には $2 \%$ の AEAPS 水溶液で修飾した多孔性ガラス を䀧とし，両僋のセルの溶液中に同じ港度の塩化銅(II)が含まれ ろよ5な条件の下で，七ルの片僋の塩化カリウムの檟度を 0.01 $\mathrm{mol} \cdot \mathrm{dm}^{-3}$ に固定し, 他方の塩化カリウム暴度を变化させたとさ の俱電位の变化を測定した。その結果を四6 亿示す。塩化カリウ 么の答液中に含まれる塩化銅（II）の灌度が高くなると，膜䉓位が 低くなる。

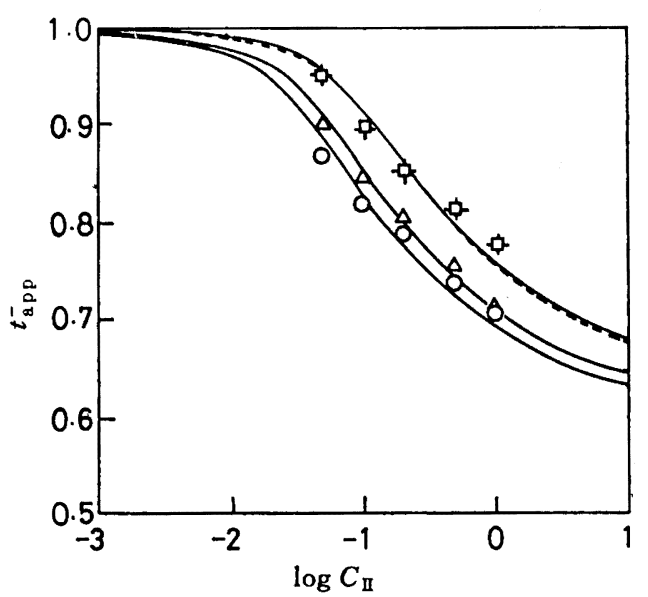

Fig. 5 Effect of concentration of the silane solution used in the surface-modification reaction on the apparent transport number of chloride in the modified glass membrane

Concentration of AEAPS solution used in the reaction was $1 \%(O), 2 \%(\triangle), 3 \%(+)$, $5 \%(\square)$

Curves are the best-fit curve as in Figs. 3 and 4

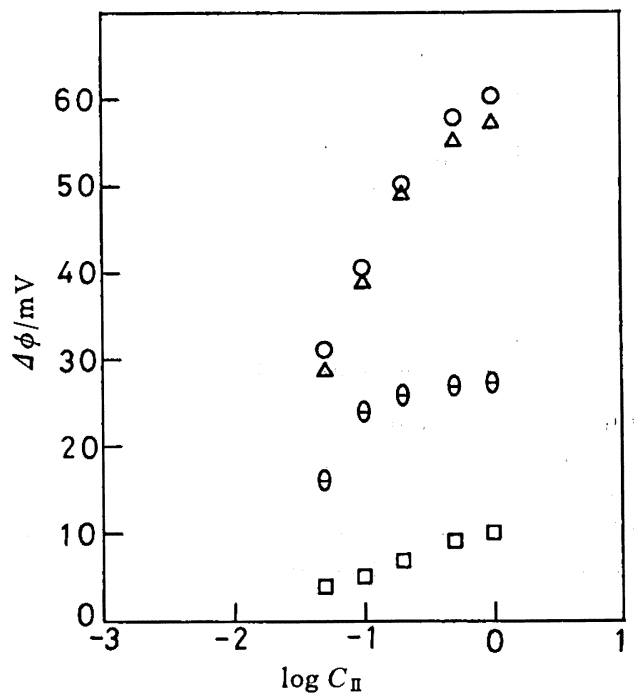

Fig. 6 Effect of $\mathrm{Cu}$ (II) ion on the membrane potential across AEAPS-modified porous glass membrane

$\mathrm{KCl}$ concentration on the left side is $0.01 \mathrm{~mol}$. $\mathrm{dm}^{-3}$, and that on the right sideis is $C_{\text {II }}$ $O$; without $\mathrm{CuCl}_{2}, \triangle$; with $0.001 \mathrm{~mol} \cdot \mathrm{dm}^{-3}$ $\mathrm{CuCl}_{2}$ added on both sides, $\theta$; with $0.01 \mathrm{~mol}$. $\mathrm{dm}^{-3} \mathrm{CuCl}_{2}$ added on both sides, $\square$; with $0.1 \mathrm{~mol} \cdot \mathrm{dm}^{-3} \mathrm{CuCl}_{2}$ added on both sides

\section{4 考察}

4. 1 Theorell-Meyer-Sievers モテルとの比較 図 3 の曲線は Theorell-Meyer-Sievers の式 :

$\Delta \phi_{\mathrm{TMS}}=\mathrm{I}$ 相と膜相の間の Donnan 電位 


$$
\begin{aligned}
& \text { 十膜内の抬散電位十膜相と II 相の間の Donnan 電位 } \\
&=-(R T / F) \ln \left(x / 2 C_{\mathrm{I}}\right)\left(1+\left(1+\left(2 C_{1} / x\right)^{2}\right)^{1 / 2}\right) \\
&-(R T / F)\left(t^{+}-t^{-}\right) \ln \left(\left(t^{+}-t^{-}\right)+\left(1+\left(2 C_{\mathrm{II}} / x\right)^{2}\right)^{1 / 2}\right) / \\
&\left.\left(\left(t^{+}+t^{-}\right)+\left(1+\left(2 C_{\mathrm{I}} / x\right)^{2}\right)^{1 / 2}\right)\right) \\
&+(R T / F) \ln \left(x / 2 C_{\mathrm{II}}\right)\left(1+\left(1+\left(2 C_{\mathrm{II}} / x\right)^{2}\right)^{1 / 2}\right) \quad(2)
\end{aligned}
$$

による計算値を示したものである゙。この曲線は实测値に比較的 よく一致している。また，図 4 に示した陰イオンの種類が違うと きの結果のちがいも，イオンの輸率の差によって十分説明でき る。すなわち,これは,この膜にお゙ける電位発生機構が T-M-S のモデルによって説明できることを示している。Westermann') らむ，一定の条件の下では，内壁が荷電した細孔をるつ膜を隔て た膜電位が Donnan 平衡を用いた T-M-S の式で近似できるこ

\section{とを示している。}

\section{2 固定電荷密度}

図3から得られた固定電荷密度 (体積密度) の值 $0.09 \mathrm{~mol}$. $\mathrm{dm}^{-3}$ を用いて, 細孔の直径は $40 \AA$ で, 細孔は円简形をしている と仮定し，固定電荷がこの円筒の内壁面に付いているものと考え ると，固定電荷の表面密度は次式のように計算できる。

\section{固定電荷の表面密度}

=固定電荷の体㮴密度 $\times$ (細孔の体積/細孔内の表面積)

$=5.42 \times 10^{-4}\left(\right.$ 個 $\left./ \AA^{2}\right)$

上記数値は $1800 \AA^{2}$ あたり 1 個の固定電荷が存在することを意 味している6。

修飾反応時のシラン溶液の濃度と固定電荷密度の関係を調べた 結果（図 5 ）によると, シラン溶液の濃度が $11,2,3,5 \%$ の水 溶液で修飾反応で，得られた修飾膜の固定電荷密度はそれぞれ $0.06,0.09,0.11,0.11 \mathrm{~mol} \cdot \mathrm{dm}^{-8}$ であった。因 8 から固定電荷 密度は約 $0.11 \mathrm{~mol} \cdot \mathrm{dm}^{-3}$ で飽和することが予想される。この值 をシラン 1 分子あたりの面積に換算すると $1500 \AA^{2}$ になるが，こ れはシラン分子の最小占有面積と比較すると，あまりにも大きな 值である。すなわち，ガラス表面はまだシラン分子によって完全 には扰われていないことになる。

このように固定電荷密度を限定している要因が何であるかにつ いては, 今度，検討する必要があろう。

\subsection{AEAPS による修飾の効果}

$2 \%$ の AEAPS 水溶液で修飾した多孔性ガラス膜と未修飾の多

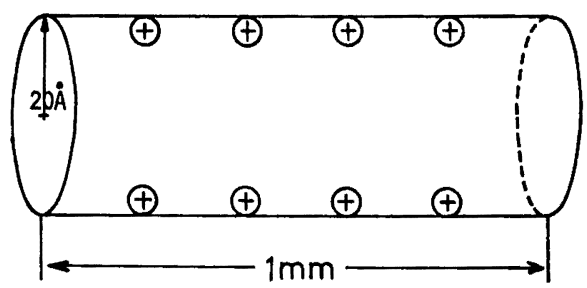

Fig. 7 Simplified pore model

The model pore has a radius of $20 \AA$ and a length of $1 \mathrm{~mm}$

5）花井哲也，“膜とイオンー物質移動の理論と計算”，化学同 人 (1978).

6) G. B. Westermann, C.C. Christoforou, J. Electroanal. Chem., 198, 213(1986).

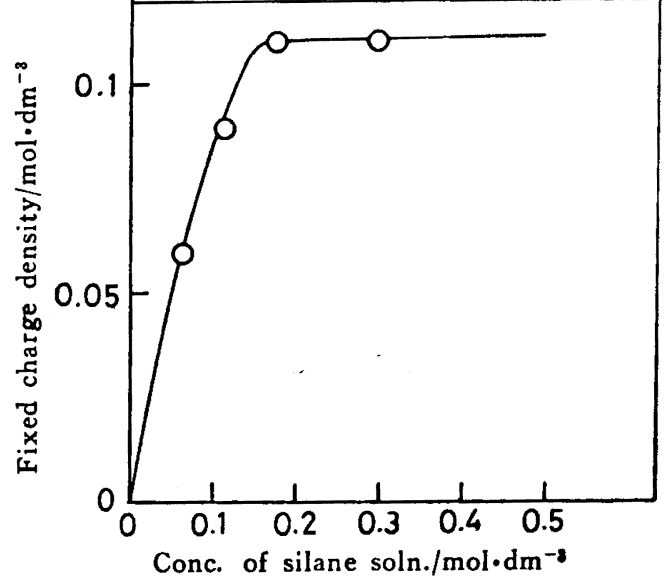

Fig. 8 Relation between fixed-charge density and the concentration of silane solution used in the surface-modification reaction

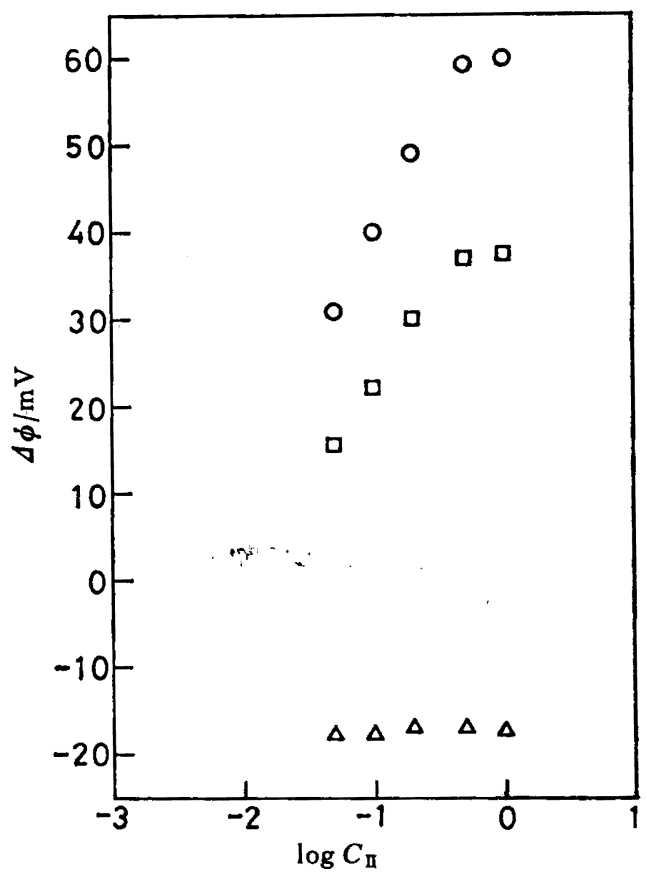

Fig. 9 Comparison of membrane potential across AEAPS-modified membrane with that across unmodified porous glass

Concentration of $\mathrm{KCl}$ on the left side is 0.01 $\mathrm{mol} \cdot \mathrm{dm}^{-8}$, and that on the right side is $C_{\mathbb{n}}$ $\mathrm{mol} \cdot \mathrm{dm}^{-8}$

$\mathrm{O}$; Porous glass modified with $2 \%$ AEAPS solution

No $\mathrm{CuCl}_{2}$ added

$\square$; Porous glass modified with $2 \%$ AEAPS solution

$\mathrm{CuCl}_{2}\left(0.01 \mathrm{~mol} \cdot \mathrm{dm}^{-3}\right)$ added on both sides

$\triangle$; Unmodified porous glass

No $\mathrm{CuCl}_{2}$ added

孔性ガラス膜のイオン選択性を四 9 に比䖝する。前に述べたよ5 に，塩化カリウムの濃度勾配をつけて，䀧䉓位を测定した。この とき膜の片側の塩化カリウムの渡は $0.01 \mathrm{~mol} \cdot \mathrm{dm}^{-3}$ に固定 
した。

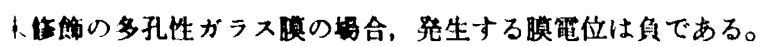
このことからこの睬は解部したシラノール基 $\left(\mathrm{SiO}^{-}\right)$のために 斌面が負に带能しているので，カチオン選択性になっていること がわか。

AEAPS を用いた飾によって，多孔性がラス膜の表面雨荷の 䈐号を反枟させることができたことは明らかである。

4.4 AEAPS で偖飾した多孔性ガラス膜裹面上での $\mathrm{Cu}(\mathrm{II})$ イオンと 2-アミノエチルアミノ基との結合

图6によると，AEAPS 水溶夜で攸飾した多孔性ガラス膜の場 合 $0.01 \mathrm{~mol} \cdot \mathrm{dm}^{-3}$ 塩化銅( II)が含まれているとさは含まれてい ないときにくらぺて，明らかに膜電位が低下していることがわか

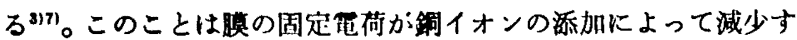
ることを示している。この原因としては，塩化銅(II)の灌度が高 いときには，Cu（II）イオンが焦飾された多孔性ガラスの表面に，

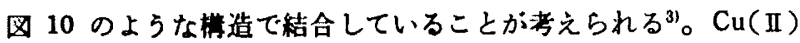
イオンの度が低い物合には，空慗原子の $\mathrm{Cu}(\mathrm{II})$ インンへの配 位数が 1 または 2 の場合も考えられるが，むともとシラン残基 が，1残基あたり 2 個の正晻荷をもっていることを考えると、一 睡位や二眍位ではシラン残基 1 個あたりの正電喜の数は減少しな いことになる。因10 のような四配位㭗造をとれば，シラン残基 1 個あたりの正電荷は1となって，Cu（II)イオンが結合する前 の二分の一となる。しかし, 膜電位の測定結果から与れば, シラ ン残基 1 個あたりの菓荷は1よりも0に近いと考えられるので， 飾ガラス表面に配位結合された $\mathrm{Cu}$ (II)イオン上の正笪荷も， 何らかの㓌イオンによって中和されている可能性がある。このよ

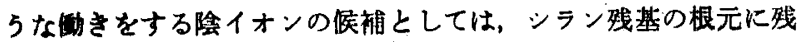
存する共有結合していないシラノール基, および, $\mathrm{Cu}$ (II)イオン に眍位できる塩化物イオンが考えられる。図10では，一応，解 離したシラノール基の存在を仮定して描いてある。 $\mathrm{Cu}(\mathrm{II})$ イオ ンの挋位棰造については，今後，さらに検矿を加えたい。

\section{5 結的前}

AEAPS を多孔性ガラスの孔内に迸入することによって，アニ

7)加藤正直，找田栄一，丧面，24，248(1986).

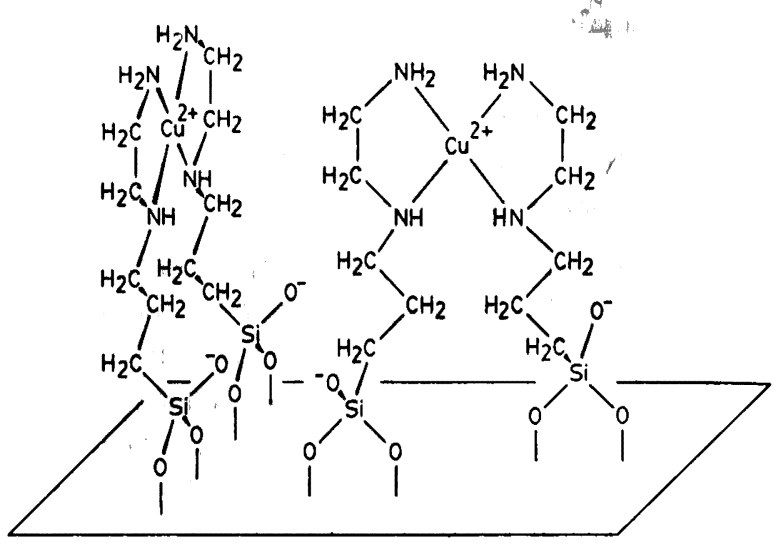

Fig. $10 \mathrm{Cu}($ II $)$ ion forming complex with [3-(2aminoethylamino)pryopyl]trimethoxysilane on porous glass surface

オン熙択性のイォン交換膜をつくったが，その結果つぎのことが 明らかになった。

（1）この膜に拉ける䉓位発生機欈かＴ-M-S のモデルによっ て説明できる。

（2）修飾した多孔性ガラスの固定電荷密度訬䬣ずるさいに 用いるシラン溶液の滥度によって変わるが, $0.11 \mathrm{~mol} \cdot \mathrm{dm}^{-3}$ で飽 和する。この值をシラン 1 分子あたりの面稓に換筑すると 1500 $\AA^{2}$ になるが，これはシラン分子の取小占有面满と比校すると非 常に大きい値である。

（3）溶液中に $\mathrm{Cu}$ (II) イオンが含まれているときは含まれて いないときにくらべて，明らかに膜のアニオンの選択能が低下し ていることがわかる。

（4）塩化カリウムの溶液中に $\mathrm{Cu}$ (II) イオンが含まれている ときの電位発生機梢は複隹であるが， $\mathrm{Cu}$ (II) イオンには修飾し た多孔性ガラス表面の 2-アミノェチルアミノ筑が配位している ものと思われる。

（5）シラン化合物を用いて表面を化学修䬦することによっ て，多孔性ガラスを種々の機能をるつ機能性膜として利用できる 可能性が示されだ。 


\title{
Special Articles on
}

Thin Films-Preparation, Structure and Properties

\author{
Modified Porous Glass with 3-(2-Aminoethylamino)propyl \\ Group as an lon-exchange Membrane \\ Tzu Hang Chiang, Asao Nakamura, Koji Nishizawa \\ and Fujio TODA* \\ Department of Bioengineering and Bioscience, Faculty of Engineering, \\ Tokyo Institute of Technology; O-okayama, \\ Meguro-ku, Tokyo 152 Japan
}

Transport of ions across the membranes was studied by use of porous glass (average pore radius of $20 \AA$, corning $\$ 7930)$ modified with [3-(2-aminoethylamino)propyl]trimethoxysilane. Membrane potential was generated in the system with two aqueous solutions of different concentration of $\mathrm{KCl}, \mathrm{KNO}_{3}$, or $\mathrm{CH}_{3} \mathrm{COOK}$ separated by the modified membrane. (Fig. 4) The membrane potential agree with the Theorell-Meyer-Sievers Theory. The fixed charge density of the modified porous glass membrane increased with the increase of the concentration of silane solution used in the modification reaction, while saturated at higher concentration than $0.01 \mathrm{~mol} \cdot \mathrm{dm}^{-3}$. This means a unit fixed charge occupies the area of $1500 \AA^{2}$ on the glass surface. This value is too large if compared with the least crosssectional area of one silane molecule. The addition of copper(II) ion in $\mathrm{KCl}$ solution decreased the membrane potential. It was presumed that copper(II) ion forms a complex with aminoethylamino groups on the modified porous glass surface, which might lower the fixed charge density of the modified membrane. 